\title{
THE NATURE OF THE DIVISION INTO PUBLIC AND PRIVATE LAW, WITH PARTICULAR EMPHASIS ON POLISH EXPERIENCES
}

\begin{abstract}
Rafat Szczepaniak generally agrees with the ideas expressed by some contemporary lawyers that the division of the legal system into public and private law is multifunctional and dependent on a wide variety of contexts, and that it is a non-dichotomous division. Although, according to Rafat Szczepaniak, the idea of non-dichotomous division is not particularly revealing as one can encounter similar statements in European jurisprudence made throughout the twentieth century, the merit of the above-mentioned lawyers is to draw attention to the momentous consequences of this idea, including in the sphere of human rights the protection of human rights against the undue interference of the state and that of other public bodies. The main thesis of the present article can be summarized by the assertion that the non-dichotomous division into public and private law has a significant impact on the outcome of the rulings of courts. The author draws examples from cases heard in Polish courts since for obvious reasons Polish legal practice is that best known to him. At the same time the Polish examples presented in the article prove that the distinction between public and private law is of universal importance regardless of whether we take into consideration the Polish legal system or the legal systems of the other European countries.

In conclusion, the author formulates the postulate de lege ferenda to distinguish a subset of private law regulating the activity of the administration.
\end{abstract}

\section{Keywords}

division into public law and private law - public law contract - the non-dichotomous nature of the division into public and private law

\section{INTRODUCTION}

In the science of law the importance of the division of the legal system into public and private law has been discussed for decades if not for several centuries ${ }^{1}$. Extreme views are expressed on this division. According to many

Dr hab. Rafał Szczepaniak - scientist of the Faculty of Law at Adam Mickiewicz University in Poznań; Chair of Civil, Commercial and Insurance Law. 
theorists it deserves to be called a distinction of the highest importance, because it results from the nature of the law itself ${ }^{2}$, while others question the sense of introducing it at all ${ }^{3}$. It seems that everything has already been written about the essence of this division in the science of law. It is therefore difficult to come up with a completely new and insightful thought here. Nevertheless, the statements that bring some order into the discussion on the essence of the division of the legal system into private and public law are worth noting. A large number of different theories, often conflicting ones, that try to explain the essence of this division give the impression of chaos $^{4}$.

Ahead of further arguments I would like to express my belief that introducing this division is not a value in itself. There are many cases where sticking to this division in a faithful and strict way has actually limited the conceptual abilities of the public authorities applying the law. Also, making this distinction is not required in each and every case. This does not mean, however, that you can question the importance of it. On the contrary, the analysis of new laws and their application across the EU confirms that the divide is still alive and it is intriguing not only for theorists. What is noticeable is the great vitality and even expansiveness of this division. One can even get the impression that while theorists, as we have seen, often question its importance, in the circles of practising lawyers dealing with legislation and applying the law this division is continuously used as a justification for the adoption of specific regulations and decisions. The importance of this division is visible at every step in the use and in the creation of law. It may be surprising as we are dealing here with a division

\footnotetext{
The origins of this division were seen in Roman law, particularly in the famous statement ascribed to Ulpian: Huius studii duae sunt positiones, publicum et privatum. Publicum ius est quod ad statum rei Romanae spectat, privatum quod ad singulorum utilitatem: sunt enim quaedam publice utilia, quaedam privatim. Publicum ius in sacris, in sacerdotibus, in magistratibus cosistit, privatum ius tripertitum est: collectum etenim est ex naturalibus praeceptis aut gentium aut civilibus. See R. Taubenschlag, Instytucje $i$ historia rzymskiego prawa prywatnego [Institutions and History of Roman Private Law], Kraków 1934, p. 24. This statement has been interpreted over centuries in various ways. See H. Müllejans, Publicus und Privatus im Römischen Recht und im älteren Kanonischen Recht unter besonderer Berücksichtigung der Unterscheidung Ius publicum und Ius privatum, München 1961, p. 17 et seq.; E. Molitor, Über öffentliches Recht und Privatrecht. Eine rechtssystematische Studie, Karlsruhe 1949, pp. 8-9.

2 See O. Gierke, Deutsches Privatrecht. Bd. 1, Allgemeine Teil und Personenrecht, Leipzig 1895, p. 29; A. Ross, On Law and Justice, London 1958, p. 203.

3 On this subject see J. Nowacki, Prawo publiczne - prawo prywatne [Public Law - Private Law], Katowice 1992, p. 6.

4 As early as the beginning of the $20^{\text {th }}$ century J. Holliger counted at least 17 such theories. See J. Holliger, Das Kriterium des Gegensatzes zwischen dem öffentlichen Recht und dem Privatrecht dargestellt im Prinzipe und in einigen Anwendungen mit besonderer Berücksichtigung des schweizerischen Rechtes, Zürich 1904, p. 11.
} 
on the highest level of generality, and to put it yet another way, with legal terms on the highest level of abstraction. Often the dilemmas law theorists are involved in are not put into practice in the application of the law. This is particularly the case with the various classifications sometimes referred to by practitioners somewhat maliciously as "academic". Another issue is, however, whether the mere fact of referring to the division in each case deserves to be assessed in a positive way and whether the regulations and legal settlements made with reference to this division are accurate and true. This question can be expressed in yet another way, that is, whether the practitioners use this division more as an inspiration or perhaps as a corset and a thinking routine that limits the ability of judges to search for the optimal, in other words, the right decision.

\section{TWO KEY STATEMENTS REGARDING THE NATURE OF THIS DIVISION}

I would like to draw attention to the views expressed in the modern European jurisprudence about the nature of this division. In my opinion, two statements are of particular importance, because they help to put in order further arguments. It is necessary to do so because, as we have seen, the cases of referring to this division in the process of adopting and applying the law are a fairly diverse collection.

\section{A. THE DISTINCTION BETWEEN PUBLIC AND PRIVATE LAW AS A CONFLICT-OF-LAW ISSUE}

The German lawyer Ch. Pestalozza noticed a seemingly obvious fact, which, however, is not always sufficiently apparent to everybody, that the issue of division into public and private law is a conflict-of-law issue. The result of assigning public or private character to a particular institution is frequently the application of conflicting legal regulations of either public or private law (Die ungeschriebene Kollissionsnorm) ${ }^{5}$. This accurate idea undoubtedly helps to introduce some order into arguments devoted to the division into public and private law. Ahead of further considerations it can be assumed that regardless of the reasons why the legislature or the authority applying the law attributed the nature of public law or private law to an institution or a legal relationship, the effect of this was to apply

5 SeeCh.Pestalozza, "Formenmißbrauch" des Staaten.ZuFigur UndFolgen des ,"Rechtsmißbrauchs" und ihrer Anwendung auf staatliches Verhalten, München 1973, p. 170 et seq. See also H. de Wall, Die Anwendbarkeit privatrechtlicher Vorschriften im Verwaltungsrecht, Tübingen 1999, p. 26. 
to the institution or the legal relationship rules belonging to the former or latter branch of the legal system. There is, thus, a close connection between the assignment of private or public character to an institution or a legal relationship and the application of the provisions of the one or the other branch of law. In the past it was very often assumed that the application of the provisions of one branch of law to an institution or legal relationship thereby precluded the application of the regulations of the other branch. In my opinion such a conflict-of-law nature of this division leads to the conclusion that this assignment may in practice be treated instrumentally, i.e. to achieve the effect of the exclusion of the application of one or another section of the legal system. The terms "public", "non-public" or "private" thus function as a kind of universal buzzwords to achieve multiple objectives. Practice proves that the motives of the legislator for using the regulations of one branch of law in a particular case, and for excluding the application of the provisions of the other can vary. At stake, among other considerations, are political objectives.

As noted by Pestalloza, the legislature frequently makes no clear criteria for assigning the public or private legal nature to a given institution or legal relationship. As a rule, it also avoids directly defining an institution or a legal relationship as public or private ${ }^{6}$. The fact that the legislature usually does not expressly define the nature of an institution or a legal relationship

$6 \quad$ The literature provides a unique case, when lawmakers tried to legally define the term "public law". It was about the rejected draft of Württemberg law on Administrative Procedure, 1931 (Art. 1). The wording of this provision was as follows: „Das öffentliche Recht umfasst alle Verhältnisse, in denen der Staat, Körperschaften oder Anstalten als Träger der Staatshoheit einzelnen gegenüberstehen, und es umfasst außerdem die Verhältnisse, in denen der Staat, Körperschaften, Anstalten oder einzelne einander gleichgeordnet gegenüberstehen, soweit diese Verhältnisse überwiegend im öffentlichen Interesse geordnet sind". In current Polish law, in turn, one can indicate the provisions of the Act of 21.03.1985 on Public Roads (Journal of Laws of 2013, item 260), which introduces arbitrary distinction between public roads and internal (non-public) roads, although the latter also in most cases, are public property because they belong to municipalities. When it comes to municipal roads, for example, their status as a public road or internal depends on the arbitrary resolution of the municipal council. The consequences of this are far-reaching, because the use of internal roads is governed in principle by the regulations of private law. These include provisions for the protection of property rights. In addition, the responsibilities of the internal road manager are narrower than the scope of duties of a public road manager. So you can often get the impression that the division of municipal roads into internal and public roads is very instrumental and creates a legal fiction. Another example is the legal division in the Polish law of higher education institutions into "public" and "private" ones (see Art. 1, Paragraph 1 of the Act of 27.07.2005 on Law on Higher Education, Journal of Laws of 2012, item 572, which has born certain consequences, e.g., the eligibility of the relationship between the student with the university as of public or private law, and has ultimately resulted in the use of provisions either of public or private law. 
and does not specify the criteria for the assignment of a particular character means that a great role is to be played in this respect by the authorities applying the law.

\section{B. THE DIVISION INTO PUBLIC AND PRIVATE LAW AS A NON-DICHOTOMOUS, MULTIFUNCTIONAL AND CONTEXT-EPENDENT DIVIDE}

1. The claim of the conflict-of-law character of the division into public and private law is essentially correct, it does not mean, however, that it does not deserve further discussions and corrections. In recent times, the analysis of the nature of this division was taken up by Gerdy Jurgens and Frank van Ommeren ${ }^{7}$, who made a case for the multi-functionality and contextdependence of this distinction, as well as its non-dichotomous character. It seems that the latter is the most important feature of this subdivision. The non-dichotomous nature is manifested in the multi-functionality and context dependence. In other words, the multi-functionality and context dependence reflect the non-dichotomous nature of this division.

2. Assigning a public or private nature to an institution is conditioned by the desire to achieve various objectives. In addition, various contexts determine how it is carried out. As follows from the foregoing considerations, the thought is not particularly revealing. It had previously been expressed almost in the same way by other lawyers including the Polish theorist J. Nowacki, who wrote that "the values of "public» and "private» are assigned to certain phenomena, but they are not discovered in them; there does not exist an empirically testable criterion independent of a particular entity, allowing us to distinguish between what is public and what is private" ${ }^{8}$. "The distinction between public and private law and assigning the value "public» to the whole of law is not a matter of knowledge, but a matter of approval and recognition of certain values, certain political or socio-political ideology. Hence, such far reaching divergences in positions of various authors who are not aware of the evaluating (ideological) nature of their statements when they divide the law into private and

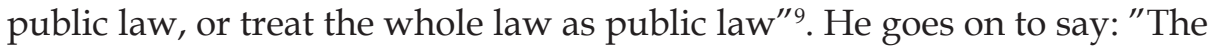
understanding of the predicate «public» (e.g. «the public interest», «public

G. Jurgens, F. van Ommeren, The Public-Private Divide in English and Dutch Law: A Multifunctional and Context - Dependant Divide, Cambridge Law Journal 2012, vol. 71(1), pp. 172-199.

See Nowacki, supra note 3, p. 107.

Ibidem, p. 132. 
good») sometimes appearing in a legal text is entirely dependent on what is assessed as public by a given entity in a given context"10.

These attributes of this distinction that Gerdy Jurgens and Frank van Ommeren referred to as multi-functionality and context-dependence make the distinction become, in a sense, relative, dependent on arbitrary subjective assumptions made by those who conduct such division, reject or accept it, and is dependent on the goals they intend to achieve ${ }^{11}$.

The fact that other theorists presented views in a similar spirit to that of Gerdy Jurgens and Frank van Ommeren much earlier, does not mean that the statements of these two authors do not bring anything new. The authors have in a way re-examined this division in contemporary realities. Their reflections have been made in an interesting comparative legal background. They examined the functions performed by this division in individual cases. They also analyzed complex contexts in which it is manifested. The authors compared British and Dutch law, which increases the cognitive value of their analysis. As is widely known, Dutch law belongs to the family of continental law, where the traditional distinction between private and public law is emphasized. The tradition of Anglo-Saxon law, on the other hand, was characterized by ignoring this division as a matter of principle. In recent decades, the Anglo-Saxon system (e.g. in Britain and Australia) has undergone a clear transformation in this area. As the authors note, referring to this division in English law today takes place in a variety of contexts and it occurs even more frequently than in continental Dutch law ${ }^{12}$. This proves the expansiveness and vitality of the approach to the legal system as divided into public and private law, which was originally associated with the tradition of continental law. The evidence of expansion is also the practice of Central and Eastern European states liberated from the yoke of communism a quarter of a century ago. For example, the Polish legal system has always belonged to the family of the continental systems. However, for most of the second half of the twentieth century, before Poland succeeded in liberating itself from communism, the Polish legal system was inevitably stigmatised by the legal theory created by Soviet ideologists. Those theories were characterized by a strong and principal

\footnotetext{
$10 \quad$ Ibidem, p. 132.

11 In P. Cane, Public Law and Private Law. A Study of the Analysis and Use of a Legal Concept, [in:] J. Eekelaar, J. Bell (ed.), Oxford Essays in Jurisprudence, Oxford 1987, p. 65, the author wrote "The terms «public» or «private» are, in a very important sense, not descriptive terms. To say of some body or activity that it is «public» or "private» is not to say, that it possesses some «brute» characteristic but rather that, according to some norm or set of norms, the term «public» or "private» is appropriately applied to that body".

12 Jurgens, van Ommeren, supra note 7, p. 172 et seq.
} 
contestation of the division into public and private law ${ }^{13}$. However, right after the fall of the communist system the division was reintroduced in Poland, which also proves its incredible vitality.

It should also be noted that the views of Gerdy Jurgens and Frank van Ommeren, which I agree with, though not innovative, are not yet widely accepted. In the past there were often accusations against various theories distinguishing between public and private law that they do not propose objective criteria for this division, that by virtue of those theories the division is "relative" and "indefinite", that it is entirely dependent on an assessment made by those performing this division. It was to be one of the major weaknesses of those theories. Many lawyers did not want to and probably still do not want to accept the idea that the nature of this division is relative, multi-functional, and dependent on a variety of contexts, and perhaps so is to some degree the nature of law itself.

3. The same can be said of another idea aptly expressed by the authors that this division is not dichotomous, and therefore separable. As is known, dichotomy is one of the main features of the so-called logical division. It is the multi-functionality and dependence on the various contexts of this division that often makes it difficult to determine clear boundaries and sometimes it is simply impossible since such attempts are in contradiction with the nature of law. Consequently, the application of regulations of public law to an institution or a legal relationship does not necessarily exclude the application of private law to the same institution or legal relationship. This is not a revelatory statement either, as many years earlier views were voiced that it is not possible to carry out a clear division. Therefore, the following conclusion was made in the past: instead of a disjointed division, what is obtained is only some kind of typology of legal relations, a typological distinction between private and public law ${ }^{14}$. In the past one also expressed the view that many legal institutions intertwine public and private law that intermingle and complement each other, and consequently, even when considering the elements of private law, it is necessary to take into account their public aspects. Public and private law are not separated by a chasm, they overlap and a distinct boundary between them cannot be drawn ${ }^{15}$.

\footnotetext{
13 See Nowacki, supra note 3, p. 39 et seq. See also A.M. Vasil'ev, Pravovye kategorii. Metodologičskie rozrabotki sistemy kategorij teorii prava, Moskva 1976, p. 205.

14 Nowacki, supra note 3, p. 115.

15 See ibidem, pp. 115-116; J. Baumann, Einführung in die Rechtswissenschaft, München 1980, p. 30; O. Gierke, Deutsches Privatrecht, Bd. 1, Allgemeiner Teil und Personenrecht, Leipzig 1895, p. 32: "Zahlreiche Rechtsinstitute verweben Privatrecht und öffentliches Recht in ein Ganzes [...] Gehören sie mit einem bedeutenden Teil ihres Wesens jedem Gebiete an, wie etwa das Ständerecht, Gemeinderecht oder Gewerberecht, so sind sie in ihre Elemente zu zerlegen.
} 
Obviously, in the legal community one has always perceived a certain longing for a so-called logical or dichotomous division of the legal system, and so an exhaustive and disjunctive division, because, as is sometimes believed, a better order could thus be achieved. For this reason, in the past each division concerning the theory of public and private law was criticized, since they did not indicate the criteria for a logical, dichotomous division. Also, in this case one did not want to accept the fact that the very nature of law makes it impossible to carry out such a division. Importantly, when trying to make such a dichotomous division the authors understood public and private law as two opposing systems ${ }^{16}$.

\section{THESIS: THE ASSUMPTION OF A NON-DICHOTOMOUS, MULTIFUNCTIONAL AND CONTEXTUAL NATURE OF THIS DIVISION AS A FACTOR INFLUENCING THE DECISIONS OF JUDGES}

\section{A. THE ASSUMPTION OF A NON-DICHOTOMOUS, MULTIFUNCTIONAL AND CONTEXTUAL NATURE OF THE DIVISION INTO PUBLIC AND PRIVATE LAW AS A MEANS TO A MORE FLEXIBLE AND OPERATIVE USE OF PRIVATE LAW IN PUBLIC ADMINISTRATION WHILE RESPECTING THE STANDARDS OF PUBLIC LAW}

My argument is that the assumption of multi-functionality, contextdependence, and the non-dichotomous nature of the division into public and private law has a significant impact on solving practical problems in the application of the law.

In the past, this division in the European continental law was often simply absolutized. Public and private law were to be two opposite and not interpenetrating branches of the legal system. Some lawyers, especially experts in administrative law, even rejected the possibility of applying the regulations of private law to public administration whether directly or as guiding principles of the law, or by analogy ${ }^{17}$. This approach

Doch bleibt dann bei der Behandlung ihrer privatrechtlichen Bestandteile der Hinblick auf die öffentlichrechtliche Seite unerlässlich. Dagegen werden Rechtsinstitute, die überwiegend in dem einen oder andern Gebiete wurzeln, zweckmäßiger Weise ganz ihrem Heimathsgebiete eingeordnet. Darum sind bei der Darstellung der Privatrechtlichinstitute zugleich diejenigen Sätze des öffentlichen Rechts aufzunehmen, welche entweder staatliche Einrichtungen im Dienste des Privatrechts (z.B. öffentliche Bücher oder Register) begründen oder das Privatrecht durch staatliche Machmittel (z.B. Abtretungs - oder Vereinigungszwang) beschränken".

16 See Nowacki, supra note 3, pp. 114-115.

17 For example, in German legal literature, it is noted that the nineteenth-century luminaries of German administrative law (e.g. O. Mayer, P. Laband) often began their scholarly activity 
made it significantly more difficult to solve many practical problems. However, realizing that one has to deal with a multi-functional division which is dependent on a variety of contexts, and also one that by its nature is not dichotomous (logical) opens the way for a more operative and flexible application of private law as a complement to the regulations of administrative law, and, on the other hand, for the use of standards developed in public law, including constitutional law, even if the state uses forms of action belonging to private law. As is known, public law is not codified following the model of private law. Private law is more mature. Many institutions of administrative law are a kind of counterpart institutions for those of private law. There has long appeared the question of the applicability of the regulations of private law to those administrative institutions. The assumption of the non-dichotomous nature of the analyzed divide certainly leads to an affirmative answer. However there remains an open question of how to apply the provisions of private law in public administration. This application may be based on analogy or on the recognition that at least some of the rules of private law are supreme principles of law or they express these principles.

The approach characterized by the recognition of the legal system as two opposing and hermetic branches raises problems that are difficult to solve. One of the mistakes made by the authorities applying the law lies in the fact that they cling to the prior classification of an institution or social relationship as belonging to public or private law and they do not notice that at least in some contexts, this institution or relationship is of a mixed (hybrid) nature. Such a problem is noticeable in Polish jurisprudence. After the fall of communism, there appeared a number of legal institutions of a hybrid nature. This is partly the result of a reaction typical of the countries that had lived under communist regime and returned to a market economy in the last decade of the twentieth century, and partly the result of more universal trends across Europe related to the privatization of public tasks.

as civil law jurists. Abandoning civil law for administrative law with neophyte zeal they began to absolutise and dogmatise the division in public (administrative) law and private law. The consequence of this attitude was to emphasize insurmountable differences between civil law and administrative law. Therefore, they made the assumption of the completeness of the system of administrative law and the dichotomous nature of the division into public and private law. It was also a battle to create a space for administrative law as a separate emerging discipline of scientific research. In the circles of German administrative law experts one could also see the fear of civil law as as-called universal law that governs the various manifestations of social relations. O. Mayer simply did not allow even the analogous application of the civil law regulations in administrative law. See O. Mayer, Deutsches Verwaltungsrecht, Berlin 1921, Bd.1, p. 117; see also H. de Wall, Die Anwendbarkeit privatrechtlicher Vorschriften im Verwaltungsrecht, Tübingen 1999, pp. 13-15. 
In German literature the vivid term "escape of the state and municipalities from public law" (Flucht vor dem Staatsrecht) is also used for describing this process $^{18}$.

Meanwhile, the courts or other bodies applying the law are sometimes resistant to the hybrid nature and find it hard to accept. In recent years such a problem has been revealed in Poland the example being the analysis of the legal status of bailiffs.

The legal status of bailiffs (debt collectors) in Poland is of a hybrid nature. They are public officials and they use a round seal with the emblem of the Republic of Poland. Unquestionably, they are a deciding authority. They issue decisions within the judicial enforcement proceedings (e.g. Art. 768 of the Code of Civil Procedure, Art. 770 (1) of the Code of Civil Procedure). The decisions can be appealed against with the special legal means, which is the complaint (Art. $767 \S 1$ of the Code of Civil Procedure). In spite of this they perform their statutory powers and duties on their own account. The charges they collect, are usually classified as public charges, but at the same time they are the bailiff's income as income of a natural person and any statutory limitations on their retention or the possibility of their limitation are perceived by bailiffs as an attack on their constitutionally protected individual rights, as evidenced by the cases of constitutional complaints brought by bailiffs regarding the laws, which in some sense or to a certain extent limit the scope of their right to collect fees ${ }^{19}$. This hybrid character of the bailiff's legal status is somewhat similar to the legal situation of the notary in Poland. In either case, we can speak of a particular privatization of public tasks. As I have indicated above, from the beginning of the 1990-ies we have witnessed in Poland many phenomena which are manifestations of the decentralization of public administration and the broadly understood privatization of public tasks. Not always, however, were these processes followed by a comprehensive legal analysis of the events that accompanied them ${ }^{20}$.

The Constitutional Tribunal has already expressed the view that the hybrid legal status of bailiffs raises problems for the solution of which Polish

\footnotetext{
18 See B. Binder, L. Fröhler, Die Haftung der Gemeinden für ausgegliederte Unternehmungen, Linz 1982, p. 13.

19 See decision of the Constitutional Tribunal of 18.11.2003, SK 5/2002, Orzecznictwo Trybunału Konstytucyjnego [Decisions of Constitutional Tribunal] 2003, no. 9A, item 104; judgment of 30.04.2012, SK 4/2010, Orzecznictwo Trybunału Konstytucyjnego [Decisions of Constitutional Tribunal] 2012, no. 4A, item 42.

20 On the subject of privatization of public tasks as exemplified by the notary's office. See P. Biernat, Prywatyzacja zadań publicznych. Problematyka prawna [Privatization of Public Tasks. Legal Issues], Warszawa 1994, p. 89.
} 
judicature is not fully prepared. In giving its judgment of 30 April $2012^{21}$ the Constitutional Tribunal had to answer the preliminary question whether a constitutional complaint brought by a bailiff who demanded a declaration of the unconstitutionality of the provisions authorizing judicial restraint of enforcement costs is permissible. The Constitutional Tribunal finally answered this question in the affirmative. However, this conclusion was reached after apparent hesitation and with some reluctance, firstly, because the Constitutional Tribunal emphasized several times in the justification of the judgment that the bailiff is "a monocratic, state-enforcement authority", and public-law relations occur between him and the creditor as well as the debtor. As was further argued by the Constitutional Tribunal "[...] Therefore, as an entity performing the functions of a public authority, the bailiff, as a matter of principle, is not legitimized to submit a constitutional complaint. The bailiff cannot be the authority of the state and an individual protecting their constitutional rights at the same time". Despite these clear statements, the Constitutional Tribunal then contradicts itself concluding the argument with the following statement: “[...] As the bailiff is a selffinancing body, the result of business affects his personal property rights. For these reasons, the Tribunal has considered it acceptable to hear this constitutional complaint made by the bailiff owing to the matter at issue" 22 . As the Constitutional Tribunal put it in the justification of the judgment, "it recognizes the multidimensional nature of the legal position of the bailiff", and therefore "exceptionally" admitted the cassation complaint.

The final conclusion of the Tribunal is accurate. The issue of bailiff's fees, regardless of how one defines their legal nature, is inextricably linked to the legal property rights of a bailiff, which the Court finally admits though with reluctance. Consequently, one cannot question the admissibility of making these constitutional complaints by the bailiff.

The arguments of the Constitutional Tribunal can really be reduced to one sentence: the bailiff fee is of a public law nature, but at the same time the bailiff has the individual right to property, to charge a fee. In other words, we are dealing here with a phenomenon of the eclectic nature of the law.

It seems that the difficulties of the Constitutional Tribunal in making a coherent qualification of the bailiff's legal status result from excessive attachment to the traditional division between public and private law, understood as a dichotomous division. Meanwhile, in Polish law one

21 SK 4/2010, Orzecznictwo Trybunału Konstytucyjnego [Decisions of Constitutional Tribunal] 2012, no. 4A, item 42.

22 See point 1.2 of the justification of the judgment referred to in the previous footnote. 
cannot classify the bailiff solely within the category of public bodies without falling into contradiction. The breakdown of the legal system into two dichotomous and exclusive sections, i.e. private and public law, does not work. It does not withstand a confrontation with the complexity of the legal processes which we refer to as the privatization of public tasks. This phenomenon is multi-faceted. Therefore, the recognition of enforcement costs only from the point of view of public law and not recognizing the property rights of bailiffs understood as they are recognized by private law would be limiting the scope of the discourse devoted to the legal status of a bailiff.

It would be sufficient to assume that in the example of the bailiff we are dealing with a hybrid legal institution, which means that on one hand it is a public authority, while on the other hand it is an entity with its own private property rights.

\section{B. THE ASSUMPTION OF A NON-DICHOTOMOUS CHARACTER OF THE DIVISION INTO PUBLIC AND PRIVATE LAW SERVING AS A SHIELD PROTECTING THE RIGHTS OF INDIVIDUALS AGAINST LAWLESSNESS AND ABUSES OF THE ADMINISTRATIVE AUTHORITIES}

The merit of Gerdy Jurgens and Frank van Ommeren is their accurate assumption that conducting such a disjunctive division is not possible for a number of institutions and legal relationships. They provide very interesting arguments for their assertion referring to the concept of human rights and constitutional principles. They put forward the idea that every act of the state, even one made in the forms of private law, requires respect for the principles of public law, including constitutional standards protecting human rights and the rights of citizens. In some European countries one speaks of the standards of a democratic rule of law. As a result, state acts cannot be regarded as being purely of private law. And it is not just the matter of the views articulated in the doctrine. Their position is justified by the current Dutch law, it is in the Dutch Civil Code and in the General Administrative Law Act $^{23}$.

The idea that the actions of the state and other public bodies must always be assessed in terms of constitutional standards, regardless of the forms in which these actions are performed is often expressed in German literature as well. Therefore, the law governing the private law activities of the state and other public bodies must be characterized by certain features.

$23 \quad$ See Jurgens, van Ommeren, supra note 7, p. 192. 
German jurisprudence even coined the special terms Verwaltungsprivatrecht and Sonderrecht to stress the specificity of private law which is the legal basis for the activities of the state and other public entities. It seems that a similar idea can be found in the French doctrine. For example, P. Weil, wrote: "le droit privé applicable à l'administration se trouve toujours teinté de la finalité de l'intérêt général et revêt un certain particularisme [...]. Il n'est jamais identique à celui qui s'applique dans les relations entre particuliers" 24 .

In the Polish practice of applying the law, we still have a problem with accepting the fact that the legal form itself chosen by the administration for legal action does not prejudge the even deeper nature of an act undertaken in such a way. This problem is revealed especially with regard to contracts. The Polish science of administrative law has a problem with bilateral (coordinated) administrative activities, in particular with contracts. In the Polish legislation it is hard to speak about the development of any coherent institution of contract governed by public law. Also, the science of administrative law has not developed a comprehensive theory of administrative contracts. Polish twentieth-century experiences directly affect the specifics of the development of both private and administrative law.

In the communist period the principle proclaiming the unity of civil law was strongly advocated. It was expressed in Article 1 of the Polish Civil Code, in its original version. It consisted in the so called socialized trade, i.e. trade among the socialized economy enterprises, being included by the regulations of the Civil Code ${ }^{25}$. Due to the nationalization by the Communists of virtually the entire economy, all large enterprises were owned by the state and were called socialized economy enterprises. The relations between the socialized economy enterprises were covered by the regulations of private law (civil law), at the most forming a separate subgroup of civil law. Those enterprises performed, inter alia, the tasks covered by utility companies in the countries with a market economy. The contracts concluded by them, e.g. in France, are classified as administrative contracts $^{26}$. Under the previous regime in Poland, strong emphasis on

$24 \quad$ P. Weil, Le droit administratif, Paris 1987, p. 73.

25 See A. Stelmachowski, Wstep do teorii prawa cywilnego [Introduction to the Theory of Civil Law], Warszawa 1984, pp. 35, 58.

26 See F. Grzegorczyk's arguments on the concept of the so-called public enterprises, idem, Wpływ regulacji publicznoprawnych na swobode kształtowania treści umów (statutów) spótek z udziatem Skarbu Panstwa - w poszukiwaniu uzasadnienia [The Impact of Public Regulations on the Freedom to Shape the Content of the Agreements (Statutes) of Companies with Treasury Shareholding - in Search of Justification], [in:] B. Gnela (red.), Ustawowe ograniczenia swobody umów: zagadnienia wybrane [The Statutory Restrictions on Freedom of Contract. Selected Issues], Warszawa 2010, pp. 110-112. 
the principle of the unity of private law stood obviously in the way of developing a separate type of contract, i.e. a contract of administrative law. It really cannot be ignored when the specificity of Polish administration using contracts is analyzed, but after the fall of the communist regime and the return of a market economy the legal category of socialized economy enterprises ceased to exist.

Besides the processes described above yet another one has to be mentioned. In the last twenty five years the value of such phenomena as decentralization and civil society have begun to be strongly emphasized in Poland. It is so because they lead to the treating of an individual by the public authorities as a partner and allow the standards of the democratic state to be implemented. These undoubtedly legitimate views began to be accompanied by the belief that the distinction between public and private law is a reflection of two different attitudes of the public authority towards citizens. Private law is to be the exponent of the treatment of citizens by the state on the equal level, as partners. A contract as the essence of the private law method of regulation is to be concluded by definition between equals, or at least autonomous parties, even if one of them is a public authority and the other a citizen. The sole fact of conclusion of the contract as a source of regulating the relationship between the citizen and the public authority is to ensure that this relationship is released from governance, understood as the unilateral imposition of the will by a public authority upon the citizen. Consequently, there is an idea that is not even always expressed that private law is the so called good law, and so it is advisable to grant preference to all the instruments of private law, including principally the contract, at the expense of traditional forms of unilateral administrative action, the epitome of which is an administrative decision. Such assertions, characterized by far-reaching superficiality, have undoubtedly been reflected on many levels; their manifestations can also be found in court decisions.

Consequently, the Polish legislature's reference to the notion of "contract" in the legal regulations is usually interpreted by the courts and other bodies applying the law as a conflict-of-law norm suggesting the application of the provisions of private law. The problem is that the application of private law takes place mostly in a mechanical and thoughtless manner, that is, without taking into account the specifics of the entire relationship between the parties to the agreement, regardless of the fact that one of the parties is the state or e.g., an entity of local government. Parties to the agreement are treated as fully equal entities. 
For example, the justification of the judgment of the Supreme Court- Civil Chamber of 11 May 2012, II CSK 545/2011 states: “The indication of the form of contract is an example of the use by the legislature of instruments in the field of civil law to dispose of the Structural Funds and indicates the placement of entities concluding it on equal positions within the legal relationship established in this way" ${ }^{27}$. The case concerned the relationship between a legal person representing the state, i.e. the Agency for Restructuring and Modernization of Agriculture and a private entity (i.e. the so called beneficiary). As can be seen the Supreme Court adopts a kind of assumption that the use of a contract by a legal person representing the state also equipped with public-law form of sovereignty determines that the state entity and the private entity are equal parties.

Courts and other bodies applying the law do not sufficiently take into account the fact that each legal institution changes its character, at least in part, in the hands of the state. The contract as a form of administrative action will never have the same legal nature as a contract entered into between private parties. As indicated above, this idea can be encountered in the statements of the representatives of other EU countries, as well as in the Polish literature ${ }^{28}$. However, it was not sufficiently adopted by the courts and other bodies applying the law. Consequently, there may be a situation described in the Polish literature, in which the recipient of an administrative decision or a unilateral sovereign act is more protected than the party to the contract entered into with the state. In other words, it may be the case that the legal situation of the addressee of the decision of the state or a unilateral act is better than the legal situation of a private entity that is party to an agreement with the state. In fact the idea that the

$27 \quad$ Orzecznictwo Sądów Polskich [Polish Case Law Review] 2014, of. 2, item 17 with the comments by R. Szczepaniak. See also resolution of the seven judges of the Supreme Administrative Court of 29.03.2006, II 1/2006, Orzecznictwo Sądów Polskich [Polish Case Law Review] 2006, no. 11, item 122; decision of the Supreme Administrative Court of 10.02.2010, II GSK 86/2010, Lex Polonica No. 2268740.

28 For example, A. Panasiuk writes: ,[...] an agreement aiming at the realization of the public interest will be a part of the legal forms of the administration's impact on the surrounding reality. It seems, therefore, that such contracts as works concessions or partnership agreements, being part of the administration, acquire the characteristics of the instruments of public administration interaction". See A. Panasiuk, Umowa publicznoprawna (próba definicji) [Public Law Contract (An Attempt at Definition)], Państwo i Prawo [State and Law] 2008, no. 2, p. 19. On the other hand J. Lemańska highlights the differences between "ordinary" civil law contracts and civil contracts constituting one of the forms of the administration's operations. The latter are regulated not only by civil law, but by the regulations of administrative law as well. See J. Lemańska, Umowa administracyjna a umowa cywilnoprawna, Księga jubileuszowa Prof. zw. dra hab. Józefa Filipka [The Administrative and Civil Contract, Professor J. Filipek's Jubilee Book], Kraków 2001, p. 421. 
use by the administration of forms of private law by no means eliminates the risk of a breach by a public authority of civic rights and freedoms still has to pave its way. Among the Polish representatives of the science of administrative law, this view is now rather firmly established, but it cannot be said yet about the courts and other bodies applying the law.

It is difficult, for example, to consider that we are dealing with a classical contractual relationship between two equal parties, when the legislature provides for an administrative decision imposing certain obligations on the citizen if the citizen does not conclude a voluntary contract with the state that defines the scope of those duties. It is also difficult to speak of a classical contractual relationship between a state institution exercising technical supervision over technical devices and an entrepreneur, if in accordance with the regulations a condition for the entrepreneur to obtain authorization to operate technical equipment is an earlier conclusion by the entrepreneur of an agreement under which he will commission the state institution to inspect a technical device for a specific fee, the amount of which is strictly determined by legal regulations. In extreme cases it can lead to aberrations, or socially adverse effects, in particular violations of civil rights and a distortion of reality, which as described in the grounds of one of the judgments of the Polish Constitutional Tribunal consists in "the fictitious equality of parties in private law" ${ }^{29}$. The indicated judgment of the Constitutional Tribunal proves that the courts are slowly beginning to recognize the threats of the use of the so-called private-law forms of activities by the state, including, in particular, the contract.

It must be assumed that the distinction between public and private law is not dichotomous, that there are legal institutions in which the principles of private and public law do intermingle and should intermingle. In fact, each legal institution, even the one which is of private provenance par excellence, as an instrument in the hands of the government acquires certain specific characteristics. This also applies to contracts.

Thus, thanks to a proper approach to the division into public and private law as a non-dichotomous, context-dependent and multifunctional divide, we can strengthen the protection of individual rights through effective prevention of abuse on the part of the state, such abuse consisting in the arbitrary use of the regulatory methods of private or public law.

It has been pointed out in the literature of at least some of the EU countries that the choice by the legislator between institutions of private or public law should not in every case be free and unfettered. It may turn out

29 See the Constitutional Tribunal's judgment of 27.05.2014, P 51/13. 
e.g. that the choice of forms of private law by the state, and especially of the contract as a form of state action described above, creates the illusion of a voluntary character of relationship and equality of alleged partners, that is the state and the citizen, and in fact deprives the citizen of the benefit of the protection measures that would serve him if the legislature used classic administrative action. In the German literature one sees here the danger of the state manipulating individual legal institutions ("Formenmissbrauch der Verwaltung"). This risk is associated with the aforementioned phenomenon referred to by German lawyers as "Flucht ins Privatrecht" 30 . The freedom of choice of legal forms of action by the state should therefore be limited. The boundaries should be set by the constitutional principles protecting human rights and civil liberties. Similar statements can also be encountered in French texts ${ }^{31}$.

It seems that the assumption that the division of the legal system into public and private law is not a dichotomous division contributes to the shaping of the attitudes among law enforcement organs that are advantageous for the protection of individual rights against the abuses on the part of the state and other public authorities indicated above. It encourages the application of the standards for the protection of individual rights developed in public law, also in cases where the state and other public bodies use the private-law forms of action.

\section{POSTULATE DE LEGE FERENDA: THE NEED TO EXTRACT A SUB- GROUP OF PRIVATE LAW REGULATING THE ACTIVITY OF THE ADMINISTRATION IN THE FORMS TYPICAL OF PRIVATE LAW}

It is rightly noted that any suggestions made on the basis of comparative considerations and especially using examples from the law of other countries must be done with extreme caution ${ }^{32}$. It is very difficult to draw conclusions without taking into account the different, often centuries-old,

\footnotetext{
$30 \quad$ See Pestalozza, supra note 5, p. 170 et seq.; de Wall, supra note 5, pp. 21-22.

31 The concept of "détournement de procédure" is known in the French doctrine and jurisprudence of administrative law. It is a specific form of abuse by the legislature in the process of applying the law or by the administration itself in the process of the application of the right to choose the forms of administrative actions. It happens that the public authority chooses out of several possible forms of the administration activity the one that provides the greatest ease of attaining the objective pursued. This allows the authority to avoid a procedure ensuring the protection of citizens' rights. See A. Laubadère, J.C. Venezia, Y. Gaudemet, Traité de droit administratif, Paris 1994, p. 501.

32 See on this subject K. Ziemski, Indywidualny akt administracyjny jako forma prawna działania administracji [Individual Administrative Act as a Legal Form of the Administrative Action], Poznan 2005, p. 143.
} 
experience of individual countries. Surely it would not be appropriate to thoughtlessly transplant to one country the legislation and institutions developed in other countries. Also, evaluating the state of development of the science of law in a particular country by the simple comparison of institutions and arrangements established in different countries may lead to confusion. There are far-reaching differences between European countries when it comes to matters covered by the regulation of public and private law, as evidenced for example by the cases concerning contracts as a form of administrative action. The multi-functionality and context-dependence of the division into public and private law becomes evident here. Analysis of the development of Polish administrative (public) law and of that of other EU countries reveals the extent and scale of these differences, contrary to the popular belief that the legal systems of the countries of Continental Europe are so close to each other. Differences exist, among other things, in relation to such fundamental issues as the system of sources of law and the scope (object) of administrative law ${ }^{33}$. Sometimes one is even faced with the phenomenon of the untranslatability of the legal or lawyers' language ${ }^{34}$ of the individual states. It can even be argued that comparative studies of the different institutions of administrative law as well as e.g. of the contract as a form of administration activities are less useful than comparative studies within private law. Administrative law is in fact much more susceptible to the influence of various concepts of political science and is a function of the system adopted in a given country and the prevailing view of the role and tasks of the state ${ }^{35}$. The science of private law, of course, also depends on these factors, but to a lesser extent, due to its greater maturity, including the all-powerful legacy and tradition of Roman law.

The caution expressed above with regard to comparative studies of administrative law should always be taken into account by researchers analyzing the various institutions operating in different countries.

Nevertheless, it seems reasonable to express the assertion of a universal nature, and thus related to the legal systems of all EU member states that it is reasonable to extract a branch of law regulating the activities of the

33 In France, for example. the administrative law in large part determined by the jurisprudence of the Supreme Administrative Court - Council of State. French authors happily compare the activities of the Council of State to the work of the ancient Roman Praetor (les oeuvres prétoriennes). See de Laubadère, Venezia, Gaudemet, supra note 31, p. 843; P. Duez, La responsabilité de la puissance publique, Paris 1938, p. 5.

34 In Polish legal theory there is a distinction between "legal language" and "lawyer's language". The former is the language of legal texts, the latter the language used by the lawyers in discussions about the law.

35 See on this subject J. Łętowski, Au carrefour de l'administration contemporaine, Wrocław-Warszawa-Kraków-Gdańsk-Łódź 1990, p. 54. 
state and other public entities undertaken in the so-called forms of private law. In the past, as is known, consumer law was established as a subset of private law. Underlying this separation lay the idea that the consumer is a weaker subject in relation to the entrepreneur, and therefore requires greater legal protection. As a result, regulations constituting a derogation from the general rules of private law were developed.

Since, according to general sentiment, the entrepreneur is in a stronger position compared with the consumer with whom he concludes an agreement, it is more the case with regard to the expanded administrative machine with its well-trained officers as well as public-law sovereignty. In addition, the administration often takes advantage of its monopolist's position within the meaning of the so-called natural monopoly. The privileged situation of the organizational entity of the state occurs regardless of the legal form in which the entity takes action. This may be either an administrative decision or a so-called agreement within the meaning of private law. As the classic Polish jurists of administrative law J. Starościak wrote, the entire scope of activities of the administration bears the hallmarks of public power ${ }^{36}$.

\section{CONCLUSION}

The author of this publication does not undermine the a priori meaning and significance of the division of the legal system into public and private law.

The above arguments show, however, that the division into public and private law cannot be seen as an absolute, dichotomous division. Of course, someone could use as an argument against the non-dichotomous character of this division the view expressed in the nineteenth century that certain rules of private law are an expression of the guiding principles of the entire legal system. Consequently, for this reason, they must also be applied in public law, but not as rules of private law, but as guiding principles of the entire legal system. Such an argument does not explain, however, the need for using public law standards by the administration applying private-law forms of action.

An additional argument against absolutizing this division is provided by the attitude of legislators in the contemporary world. They often

36 See J. Starościak, Prawne formy i metody działania administracji [Legal Forms and Methods of Administrative Actions], [in:] J. Starościak (ed.), System prawa administracyjnego [The System of Administrative Law], vol. III, Wrocław 1978, pp. 167-176. 
apply civil (private) law and administrative law methods of regulation in an alternating manner and do it without any particularly profound justification.

Such an attitude is encountered not only in the case of Polish legislators, but also in other European countries and it is the subject of legal analysis there. It is noted that this attitude of the legislators often appears to be a form of juggling with various methods of regulation. It is often hard to find the deeper thoughts which inspired the legislator in the choice between the two above-mentioned opposing methods of regulation. Therefore, the view that the choice of method made by the legislator is often accidental is sometimes expressed in the doctrine ${ }^{37}$. It is sometimes the case that, with regard to very similar social relations, the legislature on one occasion uses the administrative and on another the private law methods of regulation. All the more so there is no point in attaching an excessive importance to the division into public and private law. In particular, it makes no sense to treat it as a dichotomy, that is an opposition, and an almost hermetic division.

The legal system is, or at least should be coherent. Its coherence is not violated if we accept that in the legal system there are institutions and relations that are of a mixed nature, in which various legal issues converge, and to which we apply the rules of private and public law. In contrast, what certainly threatens the coherence of the legal system is thoughtlessly setting impassable demarcation lines between public and private law. Drawing such limits should not be an end in itself. Each time one should ask the question what purpose such a division is to serve and what its practical consequences are ${ }^{38}$. In particular, this traditional division should not preclude the use in the broadly understood public sector of specific guiding principles, only because they were developed by civil law experts, and the application of standards of public law e.g. aimed at the protection of human rights in administrative activities undertaken in the forms of private law (e.g. contracts). That coherence of the legal system requires that certain rules be regarded as guiding principles of the entire legal system. Meanwhile, the traditional distinction between public and private law sometimes resembles a corset excessively limiting the effectiveness of the legal system because it is wrongly understood as a dichotomous division.

37 E.g. with regard to German law see H. de Wall, Die Anwendbarkeit privatrechtlicher Vorschriften im Verwaltungsrecht, Tübingen 1999, p. 87.

38 See R. Szczepaniak, Sens i nonsens podziału na prawo publiczne i prywatne [Sense and Nonsense of the Division into Public and Private Law], Państwo i Prawo [State and Law] 2013, no. 5, p. 38 et seq. 
In contrast, one of the most important manifestations of the effectiveness of the legal system is the ability to remove the conflict between the so-called letter of the law and equity.

It is therefore not surprising that even those institutions with a private law pedigree are of interest to the study of administrative law if they are used by the state and other public bodies. Consequently, the optimal solution is to undertake research on such institutions as are used in public administration by representatives of private law and administrative law. Today we are dealing with a renaissance of interdisciplinary approaches in the humanities and social studies ${ }^{39}$. It is reflected, among other ways, in the demands for a comprehensive analysis of various social phenomena, i.e., taking into account the achievements of economics, law, psychology, or sociology. The attitude which is characterized by a strict maintenance of divisions within the science of law alone seems therefore a bit archaic.

If the above arguments that the division into public and private law is not a logical division, and so it is not dichotomous and exhausting, seem unconvincing to the reader, we can still recall the statement of an outstanding judge of the federal Supreme Court of the United States Oliver Wendell Holmes who wrote: "The life of the law has not been logic, it has been experience" ${ }^{\prime 4}$.

39 See Z. Kloch, Interdyscyplinarność w naukach społecznych i humanistycznych - możliwości iograniczenia [Interdisciplinarity in the Social Sciences and Humanities - Possibilities and Limitations], available at: http://www.obta.uw.edu.pl/pl-61.

40 According to R. Serick, Rechtsform und Realität Juristischer Personen, Berlin-Tübingen 1955, p. 103. 
